\title{
Aplikasi Metode Pembelajaran Kooperatif Tipe STAD terhadap Tingkat Kognitif Mahasiswa pada Mata Kuliah Anatomi dan Fisiologi
}

\author{
Yulifah Salistia Budi \\ STIKES Banyuwangi, Banyuwangi, Indonesia \\ Email Korespondensi: yulifahsalistia@gmail.com
}

\begin{abstract}
Introduction: STAD is a type of cooperative learning method that emphasizes collective attitudes or behaviors in working or helping among others in an orderly structure of cooperation in groups. The application of the STAD type learning method is carried out to determine the cognitive level of students in understanding the concept of a subject. The purpose of this study was to determine the effect of the application of the STAD learning method on students' cognitive levels. This research was conducted on 40 midwifery students in the 2018/2019 academic year Method: Using one group pre post test design with the Wilcoxon statistical test. Results: From the results of the Wilcoxon statistical test using the SPSS program, it was found that the $Z$ value was -5.261 with a $p$ value Asymp. Sig (2-tailed) of 0,000 where the critical limit of the study is 0.05 , which means $H 1$ is accepted or which means that there is a significant difference between the pre and post test values after the STAD learning method is carried out. By using the Wilcoxon statistical test, it was found that there was a significant difference between the pre and post test values after the STAD learning method was carried out.Conclusion: The conclusion of this study is that the application of the STAD can increase students' knowledge of the material presented by educators so that there is interaction between students to motivate and help each other in mastering the subject matter in order to achieve maximum achievement.
\end{abstract}

Keyword: cooperative,learning method, Student Team Achievement Divisions.

\begin{abstract}
Abstrak
Pendahuluan: STAD merupakan salah satu jenis metode pembelajaran kooperatif yang menekankan pada sikap atau perilaku bersama dalam bekerja atau membantu diantara sesama dalam struktur kerjasama yang teratur dalam kelompok. Penerapan metode pembelajaran tipe STAD dilakukan untuk mengetahui tingkat kognitif peserta didik dalam memahami konsep suatu mata ajar. Tujuan dari penelitian adalah untuk mengetahui pengaruh aplikasi metode pembelajaran STAD terhadap tingkat kognitif mahasiswa. Penelitian ini dilakukan pada mahasiswa kebidanan tingkat satu tahun ajaran 2018/2019 sebanyak 40 mahasiswa. Metode: Menggunakan one grup pre post tes design dengan uji statistik Wilcoxon. Hasil: Dari hasil uji statistik Wilcoxon menggunakan program SPSS didapatkan hasil bahwa nilai Z -5,261 dengan p value Asymp. Sig (2-tailed) sebesar 0,000 dimana batas kritis penelitian 0,05 artinya $\mathrm{H} 1$ diterima atau yang berarti terdapat perbedaan yang bermakna antara nilai pre dan post test setelah dilakukan metode pembelajaran STAD. Dengan menggunakan uji statistik Wilcoxon didapatkan hasil yaitu terdapat perbedaan yang bermakna antara nilai pre dengan post test setelah dilakukan metode pembelajaran STAD. Kesimpulan: Kesimpulan dari penelitian ini bahwa penerapan model pembelajaran kooperatif tipe STAD dapat meningkatkan pengetahuan peserta didik terhadap materi yang disampaikan oleh pendidik sehingga terjadi interaksi di antara peserta didik untuk saling memotivasi dan saling membantu dalam menguasai materi pelajaran guna mencapai prestasi maksimal.
\end{abstract}

Keyword : metode pembelajaran, kooperatif, STAD

Budi, Y.S., Aplikasi Metode Pembelajaran Kooperatif tipe STAD 


\section{PENDAHULUAN}

Dalam dunia pendidikan saat ini, peningkatan kualitas pembelajaran baik dalam penguasaan materi maupun metode pembelajaran selalu diupayakan. Salah satu upaya yang dilakukan pendidik dalam peningkatan kualitas pembelajaran yaitu dalam penyusunan berbagai macam skenario kegiatan pembelajaran di kelas. Pembelajaran merupakan perpaduan antara kegiatan pengajaran yang dilakukan pendidik dan kegiatan belajar yang dilakukan oleh peserta didik. Dalam kegiatan pembelajaran tersebut, terjadi interaksi antara pendidik dengan peserta didik, peserta didik dengan peserta didik maupun interaksi antara peserta didik dengan sumber belajar. Diharapkan dengan adanya interaksi tersebut, peserta didik dapat membangun pengetahuan secara aktif, pembelajaran berlangsung secara interaktif, inspiratif, menyenangkan, menantang, serta dapat memotivasi peserta didik sehingga mencapai kompetensi yang diharapkan.

Pembelajaran menggunakan diskusi kelompok sudah sering dilakukan oleh pendidik, tetapi pembelajaran yang bagaimanakah yang memenuhi pembelajaran kooperatif yang perlu diketahui oleh pendidik? Selain itu, materimateri apakah yang "sesuai" apabila menggunakan pembelajaran kooperatif? "Sesuai" disini dalam arti dapat diterapkan di kelas dan mendapatkan hasil yang optimal. Menurut Anita, Lie (2002), situasi dalam kelas perlu direncanakan dan dibangun sedemikian rupa sehingga peserta didik mendapatkan kesempatan untuk berinteraksi satu sama lain. Dalam interaksi ini, akan terbentuk suatu komunitas yang memungkinkan mereka untuk memahami proses belajar dan memahami satu sama lain. Diharapkan, pendidik dapat menciptakan situasi belajar sedemikian rupa sehingga peserta didik dapat bekerjasama dalam kelompok serta mengembangkan wawasannya tentang pembelajaran kooperatif. Melalui pembelajaran kooperatif, diharapkan pendidik dapat mengelola kelas dengan lebih efektif.

Menurut Slavin (2009) bahwa metode kooperatif tipe STAD merupakan salah satu metode yang menekankan pada adanya aktivitas dan interaksi di antara peserta didik untuk saling memotivasi dan saling membantu dalam menguasai materi pelajaran guna mencapai prestasi maksimal. Menurut Trianto (2011) pembelajaran kooperatif tipe STAD adalah model pembelajaran kooperatif dengan menggunakan kelompok-kelompok kecil dengan jumlah anggota tiap kelompok 4-5 peserta didik secara heterogen, yang merupakan campuran menurut tingkat prestasi, jenis kelamin, dan suku. Diawali dengan penyampaian tujuan pembelajaran, penyampaian materi, kegiatan kelompok, kuis, dan penghargaan kelompok.

$$
\text { Menurut Adesanjaya }
$$

kelebihan dan kelemahan model pembelajaran kooperatif tipe STAD adalah sebagai berikut. 1. Kelebihan model pembelajaran kooperatif tipe STAD, yaitu: 1. Memberikan kesempatan kepada peserta didik untuk menggunakan keterampilan bertanya dan membahas suatu masalah. 2 . Memberikan kesempatan kepada peserta didik untuk lebih intensif mengadakan penyelidikan mengenai suatu masalah. 3 . Mengembangkan bakat kepemimpinan dan 
mengajarkan keterampilan berdiskusi. 4 . Memberikan kesempatan kepada peserta didik untuk mengembangkan rasa menghargai, menghormati pribadi temannya, dan menghargai pendapat orang lain.

2. Kelemahan Model Pembelajaran Kooperatif Tipe STAD, yaitu: Kerja kelompok hanya melibatkan mereka yang mampu memimpin dan mengarahkan mereka yang kurang pandai dan kadangkadang menuntut tempat yang berbeda dan gaya-gaya mengajar berbeda. Untuk mengatasi hal tersebut diperlukannya keterampilan pendidik dalam manajemen kelasnya, pendidik mampu menyatukan peserta didik dengan berbagai keanekaragamannya dalam kelompokkelompok kecil sehingga dapat mengatasi kelemahan dalam penggunaan model pembelajaran ini.

Terdapat enam langkah utama atau tahapan di dalam pelajaran yang menggunakan pembelajaran kooperatif (Trianto dalam Ibrahim, dkk 2010), pelajaran dimulai dengan pendidik menyampaikan tujuan pelajaran dan memotivasi peserta didik untuk belajar (tahap 1). Fase ini diikuti oleh penyajian informasi, seringkali dengan bahan bacaan daripada secara verbal (tahap 2). Selanjutnya, peserta didik dikelompokkan ke dalam tim-tim belajar (tahap 3). Tahap ini diikuti bimbingan pendidik pada saat peserta didik bekerja bersama untuk menyelesaikan tugas bersama mereka (tahap 4). Fase terakhir pembelajaran kooperatif meliputi presentasi hasil akhir kerja kelompok, atau evaluasi tentang apa yang telah mereka pelajari (tahap 5) dan memberi penghargaan terhadap usaha-usaha kelompok maupun individu (tahap 6).

Berdasarkan wacana diatas maka disini penulis akan menerapkan metode pembelajaran Cooperative Learning tipe STAD (Student Team Achievement Divisions) sesuai dengan capaian pembelajaran mata kuliah, dengan harapan dapat mencapai level taksonomi pada capaian pembelajaran mata kuliah tersebut.

\section{METODE}

Pada artikel ini penulis menggunakan metode one group pre post test, dengan uji statustik Wilcoxon menggunakan aplikasi SPSS versi 25 . Populasi yang digunakan adalah semua mahasiswa kebidanan yang mengikuti mata kuliah anatomi dan fisiologi pada T.A 2018/2019, dengan jumlah responden yaitu sebanyak 40 peserta didik yang dibagi menjadi 8 kelompok dengan $100 \%$ perempuan pada semester satu program studi D3 Kebidanan yang mengikuti mata kuliah anatomi dan fisiologi. Untuk mengetahui tingkat kognitif, menggunakan soal pilihan ganda terkait dengan materi yang telah disampaikan dengan tahapan sesuai dengan fase pada metode STAD. Kemudian, dilakukan rekapitulasi hasil peningkatan kognitif dan penghitungan statistik.

\section{HASIL}

Dari implementasi metode tersebut diperoleh hasil bahwa perubahan nilai pre dan post test peserta didik, didapatkan peningkatan skor sebanyak 36 mahasiswa, mengalami penurunan 1 mahasiswa dan tetap 3 mahasiswa. 
Tabel 1. Distribusi Perubahan Nilai Pre dan Post Test setelah Aplikasi STAD

\begin{tabular}{lcc}
\hline $\begin{array}{l}\text { Distribusi } \\
\text { Perubahan } \\
\text { Nilai }\end{array}$ & $\begin{array}{c}\text { Jumlah } \\
\text { Mahasiswa }\end{array}$ & $\%$ \\
\hline Peningkatan & 36 & 90 \\
Tetap & 3 & 7,5 \\
Penurunan & 1 & 2,5 \\
\hline
\end{tabular}

Tabel 2. Hasil Uji Statistik Wilcoxon

\begin{tabular}{lr}
\hline & Post-Pre \\
\hline $\mathrm{Z}$ & $-5,26$
\end{tabular}

Asymp. Sig. (2-tailed) , 000

Sumber : Data diolah SPSS vers. 25

Dari hasil uji statistik Wilcoxon menggunakan program SPSS didapatkan hasil bahwa nilai $\mathrm{Z}-5,261$ dengan $\mathrm{p}$ value Asymp. Sig (2-tailed) sebesar 0,000 dimana batas kritis penelitian 0,05 artinya $\mathrm{H} 1$ diterima atau yang berarti terdapat perbedaan yang bermakna antara nilai pre dan post test setelah dilakukan metode pembelajaran STAD.

\section{PEMBAHASAN}

Dari hasil yang didapatkan saat implementasi metode pembelajaran kooperatif tipe STAD di dapatkan hasil bahwa ada perbedaan yang signifikan antara nilai pre dan post test setelah dilakukan metode pembelajaran STAD.

Menurut Arends (2008) model pembelajaran kooperatif dikembangkan untuk mencapai tiga tujuan instruksional penting, yaitu salah satunya prestasi belajar akademis. Dari beberapa penelitian yang pernah dilakukan terhadap peserta didik dengan menggunakan metode pembelajaran kooperatif tipe STAD di dapatkan hasil bahwa metode ini dapat meningkatkan hasil belajar peserta didik. Nisa, A. (2013) menyatakan bahwa Model pembelajaran kooperatif tipe STAD (Student Teams Achievement Division) dapat mengembangkan pengetahuan baik dari aspek afektif maupun aspek psikomotorik peserta didik. Sinkiriwang, Ramon (2012) menyatakan metode STAD sangat cocok diterapkan untuk mengatasi kemampuan peserta didik karena struktur penghargaan kooperatif sangat membantu dan memotivasi peserta didik dalam meningkatkan hasil belajarnya. STAD merupakan sebuah sebuah metode di mana peserta didik ditugaskan ke dalam kelompok yang berbeda, dan saling membantu menguasai berbagai topik pelajaran. Hal tersebut dikemukakan oleh beberapa peneliti. Menurut Stewart dan Sliter (2005) dalam Jahanbakhsh, Akbar A ; Mahdieh Ali Asgari Zamani ; Garman, Zahra (2019), STAD adalah metode mengajar di mana guru mempresentasikan materi dasar dan memberikan tugas untuk tim, di mana siswa mengerjakan proyek, dan terdapat uji yang diambil secara individu dan kuis serta ada pengakuan dari semua tim bahwa tim dengan kinerja terbaik mendapatkan penghargaan.

$$
\text { Metode pembelajaran ini }
$$
memberikan perubahan kognitif yang signifikan dikarenakan terdapat modifikasi pembelajaran yang memotivasi minat mahasiswa untuk belajar yaitu dengan memberikan reward dari usaha mahasiswa tersebut serta memberi kesempatan kepada mahasiswa untuk mengembangkan rasa solidaritas antar teman dengan adanya model tim pembelajaran. Tipe ini mampu mencapai aspek kognitif peserta didik sampai dengan level creating dan memberikan peningkatan yang signifikan dari segi kognitif peserta didik. Melalui 
PROFESSIONAL HEALTH JOURNAL

Volume 2, No. 1, Desember 2020 (Hal. 17-21)

https://www.ojsstikesbanyuwangi.com/index.php/PHJ

tahap ini diharapkan peserta didik akan terbiasa melakukan tugas rutinnya.

\section{KESIMPULAN}

Dari hasil implementasi di atas disimpulkan bahwa model pembelajaran kooperatif tipe STAD dapat meningkatkan pengetahuan peserta didik terhadap materi yang disampaikan oleh pendidik. Hasil tersebut didukung oleh teori Slavin (2005) bahwa metode kooperatif tipe STAD merupakan salah satu metode yang menekankan pada adanya aktivitas dan interaksi di antara peserta didik untuk saling memotivasi dan saling membantu dalam menguasai materi pelajaran guna mencapai prestasi maksimal.

\section{DAFTAR PUSTAKA}

Ade, Sanjaya. (2011). Model-model Pembelajaran. Jakarta: Bumi Aksara

Anita Lie. 2002. Cooperative Learning. Jakarta: Gramedia Widiasarana Indonesia

Arends, Ricard. (2008). Learning to Teach. Jogjakarta: Pustaka Pelajar

Ibrahim, R. (2010). Perencanaan Pengajaran. Jakarta: Rineka Cipta
Jahanbakhsh, Akbar A; Mahdieh Ali Syahbana S.Kep, Ners, M.Kes Asgari Zamani; Garman, Zahra . (2019). CIRC and STAD in Iranian context: Through the five elements to cooperative learning of lexical collocations. Seni Cogent \& Humaniora, vol. 6, iss. 1. doi: 10.1080 / 23311983.2019.1692469. Abingdon

Nisa, Afiatun. (2013). Efektifitas Penggunaan Model Pembelajaran Kooperatif Tipe Student Team Achievement Division (STAD) terhadap Hasil Belajar IPS Sejarah Peserta didik Kelas VII Di SMP N 10 Semarang Tahun Pelajaran 2012/2013. Skripsi. Universitas Negeri Semarang. Semarang

Sinkiriwang, Ramon. (2012). Penerapan Pembelajaran Kooperatif Tipe Student Team Achievement Division (STAD) dengan Metode Eksperimen untuk Meningkatkan Hasil Belajar IPA Kelas IV/A SD Negeri 08 Kepahiang. J_TEQIP, tahun III, nomor 1, 81-86

Slavin, R. E. (2009). Cooperative Learning Teori, Riset, dan Praktik. Bandung: Nusa Media

Trianto. (2011). Model Pembelajaran Terpadu. Jakarta: Bumi Aksara 